\title{
TEUNGKU MUHAMMAD DAUD BEUREUEH DAN REVOLUSI DI ACEH (1945-1950)
}

\author{
Bambang Satriya, Suwirta, Ayi Budi Santosa
}

Universitas Pendidikan Indonesia

\begin{abstract}
This research was distributed by attractions of authors to Teungku Muhammad Daud Beureueh the leader with big influence when the revolution happened in Aceh. The main issues studied in this research is "How was Teungku Muhammad Daud Beureueh's role in defending the independence of Indonesian Republic in Aceh 1945-1950?”. This study uses historical method which includes four steps: 1) Heuristics, 2) Criticism, 3) Interpretation, 4) Historiography. Based on the result, the political and socio-economic conditions in Aceh after the independence of Indonesian Republic was unstable. The role of Teungku Muhammad Daud Beureueh in Peristiwa Cumbok gave the awareness to local government to give more attention in this horizontal conflict and he instructing to mobilize the troops to attack the uleebalang clan in Pidie. He also stopped the Tentara Perjuangan Rakyat (TPR) movement who headed by Husin Al Mujahid. As the Military Governor of Aceh, Langkat, and Tanah Karo, Teungku Muhammad Daud Beureueh can merged the paramilitary organizations into TNI organization, he also the inisiator who collected the cost to buy an airplane for Indonesian government, and he can stopped the Sayid Ali movement. Teungku Muhammad Daud Beureueh rejected the merging of Aceh into the Sumatera Utara Province and this case made his disappointed to the center government and also Soekarno.
\end{abstract}

Keywords: Daud Beureueh, Aceh, Revolution, Independence

\begin{abstract}
ABSTRAK
Penelitian ini dilatarbelakangi oleh ketertarikan penulis kepada sosok Teungku Muhammad Daud Beureueh yang memiliki pengaruh besar ketika berlangsungnya masa revolusi di Aceh. Permasalahan utama yang dibahas adalah adalah "Bagaimana peran Teungku Muhammad Daud Beureueh dalam mempertahankan kemerdekaan Republik Indonesia di Aceh tahun 1945-1950?". Penelitian ini menggunakan metode historis dengan empat tahapan, yaitu: 1) Heuristik, 2) Kritik, 3) Interpretasi, dan 4) Historiografi. Adapun hasil penelitian yang diperoleh bahwa kondisi politik dan sosial ekonomi di Aceh pasca kemerdekaan tidak stabil. Kemudian, Teungku Muhammad Daud Beureueh berperan penting dalam Peristiwa Cumbok dengan memberikan penyadaran terhadap pemerintah daerah agar memerhatikan konflik horizontal yang sedang terjadi dan menginstruksikan untuk memobilisasi pasukan guna menyerang kaum uleebalang di Pidie. Ia pun mampu menghentikan gerakan Tentara Perjuangan Rakyat (TPR) pimpinan Husin Al Mujahid. Ketika menjabat sebagai Gubernur Militer Aceh, Langkat dan Tanah Karo, Teungku Muhammad Daud Beureueh mampu meleburkan berbagai laskar perjuangan ke dalam tubuh TNI, menjadi salah satu inisiator pengumpulan dana untuk pembelian pesawat terbang serta mengatasi gerakan Sayid Ali. Sikap yang diambil oleh Teungku Muhammad Daud Beureueh adalah menolak ketika Aceh hendak digabungkan ke dalam Provinsi Sumatera Utara sehingga hal ini membuatnya kecewa kepada pemerintah pusat dan Soekarno.
\end{abstract}

Kata Kunci: Daud Beureueh, Aceh, Revolusi, Kemerdekaan

Author correspondence

Email: ayibud@upi.edu

Available online at http: // http://ejournal.upi.edu/index.php/factum 


\section{PENDAHULUAN}

Masa revolusi di Indonesia tidak hanya terjadi di pusat pemerintahan seperti Jakarta dan Yogyakarta saja, melainkan terjadihampirdiseluruhwilayahIndonesia, tidak terkecuali wilayah Aceh. Wilayah yang disebutkan terakhir ini memiliki dinamika dan kekhasan tersendiri ketika masa mempertahankan kemerdekaan berlangsung. Hal ini terbukti bahwa Aceh tidak mengalami pendudukan kembali oleh Belanda. Meskipun Belanda sudah mencoba memaksa masuk, namun mereka merasa kesulitan dan hanya mampu berada di wilayah terluar Aceh. Mungkin Belanda telah belajar dari Perang Aceh bahwa rakyat Aceh sulit untuk ditaklukkan sehingga mereka mengurungkan niat untuk kembali menguasai Aceh. Oleh karena itu, dapat dikatakan bahwa Belanda tidak mampu menguasai Aceh secara keseluruhan selama masa revolusi.

Pada masa yang terkenal akan gejolak sosial dan politik ini, banyak peristiwa yang mewarnai perjalanan sejarah Aceh. Di samping itu, banyak bermunculan pula tokoh-tokoh pada masa ini. Tokoh-tokoh tersebut tidak hanya muncul, melainkan memiliki peranan yang menonjol selama masa revolusi Indonesia di Aceh. Tokohtokoh yang bermunculan pada masa itu antara lain Teuku Nyak Arif, Mr. Teuku Mohammad Hasan, Mr. S. M. Amin, Ali Hasjmy dan tidak terkecuali Teungku Muhammad Daud Beureueh yang menjadi salah satu tokoh dengan peranan penting selama masa revolusi berlangsung di Aceh.

Di Aceh pernah terjadi peristiwa penting, yakni perang saudara yang melibatkan masyarakat sipil melawan masyarakat sipil. Perang ini sering dinamakan sebagai Peristiwa Cumbok.
Seperti diketahui bahwa di Aceh terdapat dua buah kekuatan besar yakni kaum ulama yang sering disebut teungku dan kaum adat atau bangsawan dengan sebutan teuku yang biasa disebut sebagai kaum uleebalang. Beberapa hal yang membuat Peristiwa Cumbok ini terjadi adalah adanya perbedaan kepentingan antara kedua kelompok besar di Aceh ini. Kalangan uleebalang tidak seluruhnya mendukung proklamasi kemerdekaan. Mereka menginginkan Belanda untuk memerintah kembali. Hal ini senada dengan pernyataan Dewanto (2011, hlm. 8) bahwa "telah lama sebetulnya ada hubungan yang tidak harmonis antara kaum ulama dan kaum pamong praja di Aceh. Kalangan ulama menuding uleebalang hanya menjadi boneka penjajah”. Selama Peristiwa Cumbok, Teungku Muhammad Daud Beureueh (selanjutnya Daud Beureueh) memiliki peranan yang penting. Setelah Peristiwa Cumbok, posisi ulama mengalami perubahan dalam kancah perpolitikan di Aceh. Keadaan tersebut diperkuat dengan adanya gerakan Tentara Perjuangan Rakyat (TPR) yang menginginkan semua uleebalang turun dari jabatan pada pemerintah lokal Aceh. Gerakan yang dipimpin oleh Husin $\mathrm{Al}$ Mujahid ini menganggap jika mereka, para uleebalang tetap pada puncak kekuasaan, siapakah yang sanggup menjamin bahwa mereka tidak akan kembali ke tabiat yang semula (Saleh, 1992, hlm. 103). Namun, pada akhirnya gerakan ini mampu dihentikan oleh Daud Beureueh selaku golongan ulama yang memiliki posisi kuat kala itu di Aceh. Ia menganggap jika gerakan tersebut menyimpang dan condong kepada sikap Husin Al Mujahid yang ambisius akan kekuasaan. 
Selama masa revolusi, Daud Beureueh memiliki peranan yang cukup dominan. Hal initerbukti denganjabatanyang pernah ia sandang sebagai gubernur militer untuk daerah Aceh, Langkat, dan Tanah Karo. Padahal Daud Beureueh notabene hanya seorang ulama. Suatu keunikan tersendiri yang dimiliki oleh Daud Beureueh. Selama menjabat sebagai gubernur militer, ia mampu membentuk Tentara Nasional Indonesia (TNI) di Aceh. Selain itu, hal yang mungkin tidak akan pernah dilupakan oleh seluruh rakyat Indonesia adalah sumbangsih yang diberikan oleh masyarakat Aceh kepada Indonesia berupa pesawat terbang. Terkumpulnya biaya untuk pembelian pesawat terbang ini pun tidak lepas dari peranan seorang Daud Beureueh.

Dalam kunjungan Presiden Soekarno ke Aceh saat beliau berpidato di Lapangan Blang Padang, Kutaraja tanggal 16 Juni 1948. Bung Karno mengatakan bahwa Aceh adalah daerah modal. Beliau mengibaratkan Aceh sebagai sebuah payung. Kalaupun Republik hanya tinggal selebar payung, kita akan terus berjuang dengan modal daerah selebar payung itulah kita merebut daerah lain (Sufi, dkk, 1997, hlm. 70).

Namun, semua hal yang telah diperjuangkan oleh Daud Beureueh seakan tidak dihargai oleh pemerintah pusat menjelang masa revolusi berakhir. Pasca pengakuan kedaulatan kepada Indonesia sebagai hasil dari Konferensi Meja Bundar, status wilayah Aceh mengalami perubahan. Hal ini berujung kepada penolakan dari Daud Beureueh sehingga ia mulai tidak memercayai Pemerintah Pusat. Pada akhirnya, perubahan status wilayah Aceh ini berujung kepada sikap yang diambil oleh Daud Beureueh dengan memberikan perlawanan kepada pemerintah pusat.

Melihat kontribusi Daud Beureueh selama masa revolusi di Aceh berlangsung, membuat penulis menaruh ketertarikan kepada sosok ini. Khususnya peranan yang ia jalankan dan pengaruh yang ia miliki ketika membawa rakyat Aceh melewati masa-masa sulit, masa revolusi. Namun, dewasa ini Daud Beureueh seakan-akan hanya dikenal sebagai seseorang dengan predikat buruk yang tidak lain sebagai pemimpin DI/TII di Aceh. Padahal beberapa masa sebelumnya ia adalah sosok penting bagi rakyat Aceh dan Indonesia. Hal tersebut dibuktikan dengan rekam jejak yang dimilikinya. Daud Beureueh pernah menduduki jabatan yang strategis dalam dalam beberapa organisasi. Ia pernah menjabat sebagai ketua Persatuan Ulama Seluruh Aceh (PUSA), sebuah organisasi keagamaan yang bergerak di bidang pendidikan, sosial, dan keagamaan. Selain itu, pada organisasi kemiliteran, ia pernah menjabat sebagai gubernur militer yang meliputi wilayah Aceh, Langkat, dan Tanah Karo. Ia pun tak segan untuk mendorong kaum muda Aceh untuk melawan Belanda (Lapian, dkk, hlm. 1996, hlm. 14). Posisi yang pernah diemban olehnya itu, berhasil ia maksimalkan sekaligus memanfaatkannya dengan baik untuk kepentingan rakyat Aceh juga bagi kepentingan bangsa Indonesia. Tidak salah apabila Piekaar (dalam Ibrahimy 2001, hlm. 267) mengatakan bahwa "di antara ratusan, mungkin ribuan ulama-ulama di Aceh, Daud Beureueh adalah yang paling berpengaruh"

Penulis membatasi ruang lingkup yang dikaji, baik secara spasial maupun temporal. Pada aspek spasial, penulis mengambil ruang lingkup di seputar 
wilayah Aceh. Sedangkan pada aspek temporal, penulis mengambil kurun waktu dari tahun 1945 hingga tahun 1950 yang merupakan masa-masa genting bagi kelangsungan Republik Indonesia. Tahun 1945 dipilih oleh penulis sebab pada tahun ini Indonesia lahir sebagai negara baru setelah memproklamasikan diri pada 17 Agustus 1945. Sedangkan tahun 1950 dipilih karena berdekatan dengan Konferensi Meja Bundar (KMB) yang berlangsung pada tahun akhir 1949 dan berujung kepada pengakuan kedaulatan Belanda atas Indonesia yang memberikan dampak langsung kepada wilayah Aceh dan Daud Beureueh sendiri. Hal itu dapat dijadikan acuan bagi penulis mengenai sikap dari Daud Beureueh perihal perubahan status wilayah Aceh tidak lama setelah pengakuan kedaulatan dari Belanda kepada Indonesia.

\section{METODE PENELITIAN}

Metode yang digunakan dalam penelitian ini adalah metode historis atau metode sejarah. Gottschalk (1983, hlm. 32) menyatakan bahwa "metode historis merupakan proses menguji dan menganalisa secara kritis rekaman dan peninggalan masa lampau". Pernyataan tersebut, dapatmemberikanindikasibahwa seorang peneliti sejarah perlu melakukan pengujian dan analisis terhadap sumbersumber yang sesuai dengan tema penelitian yang akan dibahas yang kemudian akan direkonstruksi ke dalam bentuk tulisan setelah sebelumnya diberikan analisisanalisis yang sesuai. Adapun tahap-tahap dalam metode historis ini meliputi empat langkah penelitian, yaitu

1. Heuristik

Heuristik merupakan langkah pertama dari metode sejarah. Langkah ini mengharuskan seorang peneliti sejarah untuk mencari dan mengumpulkan berbagai macam sumber sejarah yang sesuai dengan kajian yang akan dibahas oleh peneliti tersebut. Sumber-sumber sejarah yang dapat dicari dan dikumpulkan bisa berupa sumber tertulis dan sumber lisan bahkan benda berupa dokumentasi berupa gambar atau foto. Selama melakukan pencarian sumber, penulis mengunjungi beberapa tempat seperti Perpustakaan UPI Bandung, Perpustakaan Unpad, Badan Perpustakaan dan Arsip Daerah (BAPUSIPDA) Jawa Barat, Badan Pelestarian Nilai Budaya (BPNB) Bandung, Badan Perpustakaan dan Sistem Informasi (BAPAPSI) Kabupaten Bandung, Kantor Perpustakaan dan Arsip Daerah Kota Bandung, Perpustakaan Batu API, Perpustakaan Pusat Angkatan Darat, dan koleksi pribadi penulis.

\section{Kritik}

Kritik sumber merupakan kegiatan di mana seorang peneliti sejarah melakukan klasifikasi dan penilaian suatu sumber sejarah. Hal ini dilakukan agar sumber sejarah yang telah didapatkan oleh penulis benar-benar terpercaya, sekaligus dapat dipertanggungjawabkan. Kegiatan kritik sumber terbagi ke dalam dua aspek, yaitu kritik eksternal dan kritik internal. Penulis melakukan kritik internal dengan membandingkan buku Revolusi di Serambi Mekah: Perjuangan Kemerdekaan dan Pertarungan Politik di Aceh 1945-1949 karya Nazaruddin Sjamsuddin dengan buku Peranan Tgk. Muhammad Daud Beueruh dalam Pergolakan di Aceh yang ditulis oleh Muhammad Nur El Ibrahimy. Dalam bukunya, Nazaruddin menjelaskan bahwa Teungku Muhamamd Daud Beureueh menjadi salah satu tokoh yang memiliki pengaruh besar dalam masa 
Revolusi Indonesia yang berlangsung di Aceh. Hal yang senada pun tergambar dalam karya El Ibrahimy yang sama-sama menjelaskan bahwa Teungku Muhammad Daud Beureueh menjadi salah satu pemimpin masyarakat Aceh dengan jiwa republikan yang dimilikinya.

3. Interpretasi

Interpretasi merupakan suatu penafsiran yang dilakukan oleh penulis berdasarkan hasil pemikiran terhadap keterangan atau fakta yang diperoleh dari sumber-sumber sejarah. Namun tentu saja dalam melakukan penafsiran harus tetap bersifat ilmiah. Ketika melakukan penafsiran, penulis menggunakan pendekatan interdisipliner dengan menggunakan ilmu bantu sosiologi dan ilmu politik.

\section{Historiografi}

Historiografi sendiri merupakan tahap akhir dalam metode sejarah. Pada tahap ini penulis melakukan penyusunan suatu cerita sejarah ke dalam satu kesatuan yang utuh. Penulis menyusun secara sistematis yang didasarkan kepada ketentuan yang berlaku. Pada tahap ini, penulis sejarah menerapkan kaidah penulisan supaya menghasilkan tulisan yang baik.

\section{HASIL PENELITIAN DAN PEMBAHASAN}

Teungku Muhammad Daud Beureueh, dilahirkandiBeureunun pada23 September tahun 1899. Ia dilahirkan dengan nama Muhammad Daud. Masa kecil hingga dewasa, Daud Beureueh begitu dekat dengan pendidikan Islam. Mula-mula ia belajar di Pesantren Titeue selama setengah tahun. Kemudian pindah ke Pesantren Iie Leumbeue selama empat setengah tahun (Ibrahimy, 2001, hlm. 262). Kemudian, setelah beranjak dewasa, Daud Beureueh menasbihkan dirinya menjadi ulama reformis dengan membentuk Madrasah Sa'adah Abidiyah yang merupakan inovasi dalam pendidikan Islam dari pesantren yang terbatas mempelajari ilmu agama menjadi madrasah yang memungkinkan mempelajari ilmu-ilmu lain selain ilmu agama yang dijadikan dasar.

Pada tanggal 5 Mei 1939, Persatuan Ulama Seluruh Aceh (PUSA) terbentuk di Peusangan, Bireuen, Pantai Utara Aceh (Shiraishi, 1988, hlm. 41). Secara aklamasi, terpilih Teungku Muhammad Daud Beureueh sebagai Ketua PUSA, dengan Wakil Ketua Teungku Abdurrahman Meunasah Meucap, sedangkan sebagai pelindung ditetapkan Ampon Chik Peusangan (Saleh, 1992, hlm. 17). Kebanyakan, yang tergabung dalam organisasi ini adalah ulama reformis, yang bermaksud untuk membentuk suatu wadah dalam menyatukan pikiran di antara mereka. Kehadiran PUSA diharapkan mampu meningkatkan solidaritas antara sesama ulama di Aceh supaya tidak terjadi perpecahan sesama ulama. Oleh karena itu, dibentuk organisasi bernama Persatuan Ulama Seluruh Aceh. Tidak lama kemudian PUSA masuk ke dalam MIAI (Majelis Islam Ala Indonesia) dan demikian para ulama Aceh yang tergabung di dalamnya mulai aktif melibatkan diri dalam pergerakan Islam dan perjuangan nasional Indonesia (Surachman dan Kutoyo, 1977, hlm. 214).

Pada masa Pemerintahan Jepang, pihak ulama memiliki kedekatan dengan pihak Jepang. Sebab, tujuan Jepang ke Indonesia tidak seperti Belanda yang terlebih dahulu datang. Jepang pun dianggap sebagai pihak yang telah lama dinantikan karena belum ada yang mampu mengusir Belanda. Perbedaan lainnya 
terletak dari tindakan Belanda yang kerap melakukan misi penyebaran agama sedangkan Jepang tidak melakukan hal yang demikian. Kedekatan itu terlihat dengan hubungan yang terjalin Daud Beureueh dengan pemerintah Jepang yang menunjuknya sebagai wakil Majelis Agama Islam untuk Bantuan Kemakmuran Asia Timur Raya (MAIBKATRA).

Memasuki masa kemerdekaan, keadaan politik di Aceh berjalan dengan penuh dinamika. Aceh dijadikan salah satu keresidenan yang bernaung dalam Provinsi Sumatera yang dipimpin oleh Mr. Teuku Mohammad Hasan sebagai Gubernur pertama Sumatera. Kegiatan Pemerintah di daerah Aceh baru berjalan pada awal bulan Oktober 1945, setelah keluarnya penetapan dari Gubernur Provinsi Sumatera pada tanggal 3 Oktober 1945, tentang pengangkatan pejabat pemerintah NRI di seluruh Sumatera (Surachman dan Kutoyo, 1977, hlm. 180).

Meskipun sudah dalam keadaan merdeka, namun keamanan dalam negeri harus semakin ditingkatkan. Oleh karena itu diperlukan organisasi kemiliteran yang memiliki posisi vital. Di Aceh dibentuk Angkatan Pemuda Indonesia (API) yang bertujuan sebagai pemenuhan pembentukan alat kelengkapan negara, juga untuk merebut persenjataan dari pihak tentara Jepang. Residen berpesan supaya buat sementara dipakai kata "pemuda", yang sewaktu-waktu dapat diubah menjadi "perang”, jika saatnya telah tiba (Nasution, 1977, hlm. 440).

API diprakarsai oleh beberapa pemuda bekas Giyugun (semacam PETA di Jawa) yang mempunyai gagasan membentuk organisasi keamanan. Untuk merealisisasikan gagasan tersebut pada 27 Agustus mereka mengadakan pertemuan di Hotel Sentral (Iskandar, 2000, hlm. 85). Pembentukan organisasi kemiliteran ini dimaksudkan agar keamanan di Aceh tetap kondusif dan untuk menunjang keberlangsungan pemerintahan di tengah keadaan yang belum stabil. Secara rinci, tugas API antara lain memelihara ketenteraman umum, merebut senjata Jepang, membasmi musuh-musuh proklamasi yang bersifat dan bercorak apa saja, dan memimpin gelora massa yang bergolak dengan semangat perjuangan (Wahidy, 1960, hlm. 73).

Sebelum lahir API, telah terbentuk Pemuda Republik Indonesia (PRI) di Pidie. Ketuanya Teungku Hasan Aly, yang berafiliasi dengan Barisan Pemuda Indonesia (BPI) di bawah Ali Hasjmy (Saleh, 1992, hlm. 39). PRI dan BPI kemudian berubah menjadi Pemuda Sosialis Indonesia (Pesindo) yang tetap dipimpin oleh Ali Hasjmy. Di samping Pesindo, terdapat laskar perjuangan lainnya seperti Hisbullah yang kemudian berubah menjadi Mujahidin yang dipimpin Daud Beureueh. Mayoritas anggota dari kedua laskar perjuangan ini berasal dari kalangan pendukung ulama yang tergabung dalam Pemuda PUSA. Baik Pesindo maupun Mujahidin, keduanya merupakan jelmaan dari semangat para pemuda Aceh yang memiliki tujuan sama, yakni untuk mempertahankan kemerdekaan Republik Indonesia. Tetapi, mereka memiliki keengganan untuk ikut bergabung dalam API yang kemudian menjadi pasukan resmi.

Antara API dan laskar perjuangan kepemudaan memiliki perbedaan latar belakang. API yang berkomposisikan bekas Giyugun yang memiliki pendidikan militer dan pengalaman yang cukup. Selain itu, petinggi-petinggi API pun kebanyakan 
berasal dari kalangan uleebalang yang memiliki kedekatan dengan Teuku Nyak Arif yang menjadi residen pertama Aceh setelah proklamasi kemerdekaan. Sedangkan laskar perjuangan berasal dari pemuda yang kebanyakan tergabung dalam PUSA yang memiliki afiliasi langsung dengan para ulama. API dan laskar perjuangan mewakili dua kekuatan besar di Aceh.

Sama halnya dengan kondisi politik, kondisi sosial ekonomi di Aceh pun berjalan dengan dinamika tersendiri. Keadaan yang diwariskan pasca pemerintah Jepang menduduki Aceh menimbulkan ketidakstabilan. Situasi ekonomi pada saat itu amat suram, penghidupan dan kehidupan begitu sulit. Penghidupan rakyat semata-mata tergantung dari pertanian yang hasilnya tidak seimbang bila ditukarkan dengan uang Jepang yang tak mempunyai nilai (Kodam I/Iskandar Muda, 1972, hlm. 86). Pemberlakuan mata uang sebagai alat penukaran yang sah masih mengandalkan mata uang pemerintah Belanda dan mata uang pemerintah Jepang.

Lahan-lahan produksi pertanian masyarakat tidak banyak dimanfaatkan. Pemerintah Daerah Aceh berusaha untuk meningkatkan hasil pertanian, terutama dengan cara memperluas areal persawahan. Tanah-tanah yang kosong diusahakan kembali dijadikan sawah dan ladang (Ibrahim dalam Ismail, 1995, hlm. 155). Keadaan ini diperparah dengan adanya blokade yang dilakukan oleh pihak Belanda, yang menggantikan posisi Jepang dan berkeinginan kembali menguasai wilayah Indonesia. Alasan Belanda melakukan blokade adalah untuk mencegah masuknya senjata dan peralatan militer ke Indonesia (Fahlevi, dkk, 2015, hlm. 6). Di balik blokade yang dilakukan Belanda tersimpan maksud yang dapat menjerumuskan Indonesia ke dalam lubang keterpurukan. Pemberlakuan blokade dimaksudkan agar ekonomi Indonesia mengalami kekacauan hebat sehingga rakyat tidak merasa percaya kepada pemerintah Indonesia. Meskipun begitu, semangat perjuangan rakyat tetap bergelora untuk mendukung keberlangsungan Indonesia.

Blokade yang dilakukan oleh Belanda mengindikasikan bahwa Belanda ingin kembali menancapkan kekuasaannya di Indonesia, termasuk di Aceh. Hal ini membuat geram pihak ulama di Aceh. Mereka tidak menginginkan kembali dampak sosial yang buruk terulang untuk kedua kalinya apabila Belanda kembali bercokol di Aceh. Oleh karena itu, pada 15 Oktober 1945 di Kutaraja (Banda Aceh), Teungku Haji Hasan Krueng Kalee, Teungku Muhammad Daud Beureueh, Teungku Haji Jakfar Siddiq Lambajat, dan Teungku Haji Ahmad Hasballah Indrapuri dengan mengatasnamakan seluruh ulama Aceh mengeluarkan maklumat bersama bagi seluruh umat Islam di Aceh agar turut serta dalam perjuangan menolak kedatangan kembali Belanda. Beberapa bagian maklumat ini berbunyi

"Menurut keyakinan kami, perang ini adalah perjuangan suci yang disebut "Perang Sabil". Maka, percayalah wahai bangsaku, bahwa perjuangan ini adalah sebagai sumbangan perjuangan dahulu di Aceh yang dipimpin oleh almarhum Teungku Chik di Tiro dan pahlawan-pahlawan kebangsaan yang lain. Dari sebab itu, bangunlah wahai bangsaku sekalian, bersatu padu menyusun bahu, mengangkat langkah maju ke muka untuk mengikuti jejak perjuangan nenek kita dahulu. Tunduklah dengan patuh akan segala perintah-perintah pemimpin kita untuk keselamatan tanah air, agama, dan bangsa" (Tippe, 2000, hlm. 31-32). 
Dikeluarkannya maklumat ulama di atas tidaklain bertujuan untukmemperkuat tekad dalam mempertahankan kemerdekaan. Semangat revolusi semakin berkobar di kalangan rakyat Aceh. Mereka tidak ingin kembali merasakan hal yang sama ketika Belanda menguasai wilayah Aceh sebelumnya. Otomatis, secara psikologis semangat yang dimiliki rakyat Aceh semakin berapi-api sehingga mereka rela mengorbankan jiwa dan raganya untuk meneruskan perjuangan yang baru dimulai. Terlebih dengan mengorbankan jiwa dan raga yang dianggap sebagai mati syahid dalam ajaran Islam.

Di samping itu, hubungan antara golongan uleebalang dan ulama terus mengalami gesekan menuju konflik yang tidak terelakkan. Benih-benih konflik yang telah lama ada, semakin tumbuh berkembang seiring berjalannya waktu. Tokoh uleebalang yang menjadi biang terjadinya konflik ini adalah Teuku Muhammad Daud Cumbok. Ia adalah uleebalang di daerah Sigli yang benarbenar tidak menaruh rasa simpati ketika Indonesia berhasil memproklamasikan menjadi negara yang merdeka. Dengan demikian, ia memiliki pandangan yang begitu berbeda dengan mayoritas masyarakat Aceh yang bersimpati dengan kemerdekaan Indonesia. Puncaknya, terjadi revolusi sosial yang dikenal dengan Peristiwa Cumbok di wilayah Pidie. Peristiwa ini yang pada akhirnya menggusur kekuatan dan kekuasaan uleebalang di Aceh yang menginginkan kembali kehadiran Belanda di Aceh.

Di dalam peristiwa ini, salah satu peranan yang dilakukan oleh Daud Beureueh adalah bahwa ia bersikeras di dalam sidang Komite Nasional Daerah bahwa Komite harus mengambil langkahlangkah tertentu untuk mengatasi keadaan yang gawat di Kabupaten Pidie (Sjamsuddin, 1999, hlm. 166). Memang, pada kenyataannya bentrokan ini tidaklah sekecil yang diperkirakan oleh pemerintah daerah. Maka, atas usulan dari Daud Beureueh, pihak pemerintah daerah mulai mengubah pandangan perihal konflik yang terjadi. Usulan yang diajukan oleh Daud Beureueh terbukti mampu memberikan stimulus kepada pemerintah daerah agar cepat dalam bertindak untuk menghindari hal-hal yang tidak diinginkan.

Tidak sampai di situ, Daud Beureueh menginstruksikan kepada para pemimpin PUSA di daerah Aceh Utara untuk memobilisasi para anggota Pesindo dan Mujahidin guna menyerang bagian Timur Pidie (Morris, 1990, hlm. 101). Sebagai salah satu pemimpin Persatuan Ulama Seluruh Aceh (PUSA), Daud Beureueh memiliki sokongan kekuatan dari berbagai macam elemen masyarakat. Mujahidin yang tidak lain adalah kelompok muda PUSA, memiliki kelengkapan persenjataan yang cukup mumpuni dapat dijadikan sebagai alat untuk menyelesaikan permasalahan mengenai perang saudara ini. Pertempuran secara besar-besaran tetap berlangsung dengan memakan korban yang tidak terhingga banyaknya, baik korban manusia maupun korban harta benda (Amin, 2014, hlm. 14). Pada akhirnya, pihak yang menjadi pemenang berasal dari pihak ulama. Meskipun demikian, masalah kerugian tetap saja ditanggung oleh kedua belah pihak yang berkonflik. Peristiwa Cumbok ini dapat memberi gambaran bahwa ancaman yang datang dari dalam wilayah Indonesia pun masih dapat muncul sekalipun Indonesia telah memproklamasikan kemerdekaan. 
Selepas Peristiwa Cumbok, muncul gerakan Tentara Perjuangan Rakyat (TPR) yang dipimpin ketua Pemuda PUSA, Amir Husin Al Mujahid (selanjutnya Husin Al Mujahid). Ia mengumpulkan kekuatan secara tersembunyi dari wilayah Idi melalui Pantai Timur Aceh hingga sampai ke pusat pemerintahan di Kutaraja. Ia menginginkan sisa-sisa uleebalang yang masih berkuasa agar dibabat habis dalam jabatannya. Gerakan Husin Al Mujahid adalah gerakan liar yang pada saat itu tidak dapat dihalangi oleh pemerintah daerah karena kelemahan alat-alat negara (Amin, 2014, hlm. 26). Dikatakan sebagai gerakan liar karena TPR berhasil menghimpun kekuatan yang cukup besar dengan mempersenjatai pengikutnya dengan senjata tajam dan senjata api. Saat itu belum terdapat kesatuan tentara yang dibentuk secara padu oleh pemerintah sehingga keterbatasan kekuatan pemerintah belum mampu menangkis gerakan TPR ini. Ditambah dengan situasi yang masih hangat pasca Peristiwa Cumbok sehingga semangat dari pihak Husin Al Mujahid semakin berapi-api untuk melakukan apa yang mereka inginkan. Gerakan tersebut sebenarnya menyasar kepada ambisi pribadi Amir Husin Al Mujahid yang ingin menduduki jabatan militer tertinggi.

Daud Beureueh yang merupakan ketua PUSA tidak menyadari betul tingkah yang dilakukan oleh ketua Pemuda PUSA itu. Namun, pada akhirnya gerakan TPR segera ditarik dari pedalaman Aceh karena tindakan mereka sudah dianggap menyimpang dari perjuangan (Zamzami, 1990, hlm. 46). Meskipun demikian, pada akhirnya golongan ulama dapat memanfaatkan keuntungan yang dihasilkan dari gerakan tersebut.
Menyusul Agresi Militer Belanda pertama terhadap Republik pada bulan Juli 1947, Pemerintah Pusat mengangkat Daud Beureueh sebagai Gubernur Militer Aceh (Morris, 1990, hlm. 106). Daud Beureueh diangkat menjadi gubernur militer untuk wilayah Keresidenan Aceh dan dua buah kabupaten yakni Kabupaten Langkat dan Kabupaten Tanah Karo. Pengangkatan Daud Beureueh dilakukan dan ditunjuk langsung oleh Wakil Presiden Republik Indonesia, Mohammad Hatta ketika ia mengunjungi wilayah Aceh.

Selama menjabat sebagai gubernur militer, Daud Beureueh memiliki peranan yang cukup sentral. Beberapa hal yang dilakukan olehnya antara lain melakukan reorganisasi yang mencakup rekonstruksi dan rasionalisasi tentara atau angkatan perang. Selain itu, ia pun memiliki peran dalam proses pengumpulan dana untuk pembelian pesawat terbang serta mengatasi gerakan yang dipimpin oleh Sayid Ali Alsagaf.

Daud Beureueh sama sekali tidak mengambil sesuatu langkah ke arah pembentukan TNI di Aceh sampai bulan Desember 1947 (Sjamsuddin, 1999, hlm. 220). Berhubung seluruh perhatian sedang diarahkanuntukmenghadapiAgresi Militer Belanda, maka realisasi penggabungan semua laskar bersenjata ke dalam Tentara Nasional Indonesia di daerah Aceh belum dapat diselenggarakan pada waktunya (Kodam I/Iskandar Muda, 1972, hlm. 119). Meskipun demikian, kemauan Daud Beureueh untuk mempersatukan laskar ke dalam satu tubuh bernama Tentara Nasional Indonesia tetap terlaksana.

Ketika proses pembentukan TNI, Daud Beureueh tidak hanya melakukan reorganisasi tentara negara saja, ia 
sekaligus melakukan rasionalisasi tentara yang mengacu kepada komposisi pasukan, sesuai dengan yang diinginkan oleh Mohammad Hatta perihal rasionalisasi. Keadaan ini didukung oleh pemimpinpemimpin laskar yang juga menuntut supaya TRI mengalami seleksi untuk dijadikan TNI. Dengan demikian hasil seleksi terhadap laskar dan terhadap TRI diharapkan menjadi teras penyusunan TNI (Kementerian Penerangan, 1953, hlm. 164). Di dalam pelaksanaannya, langkah ini menuai banyak ketidaksukaan dari berbagai kalangan setelah dilakukan peleburan laskar perjuangan ke dalam TNI. Ternyata banyak pihakyang tidak termasuk ke dalam tubuh TNI. Tetapi, dalam perkembangannya mereka yang tidak tergabung dalam tubuh TNI pada akhirnya merelakan ketidakikutsertaannya.

Setelah beliau memberikan penjelasan tentang tahap dan situasi perjuangan masa itu, seluruh pejuang dengan ikhlas dan taat menerima dan mengikuti perintahnya. Dan sejak itu pula puluhan ribu para pejuang Aceh dari berbagai kesatuan dengan ikhlas kembali ke masyarakat tanpa menuntut imbalan apapun, termasuk tidak menuntut Surat Keterangan Pejuang (Jakobi, 1992, hlm. 190).

Daud Beureueh mampu melakukan reorganisasi TNI di tengah situasi politik yang belum stabil dan persatuan nasional yang masih rapuh (Djumala, 2013, hlm. 23). Pada akhirnya, pendeklarasian pembentukan TNI di Aceh terjadi pada 1 Juni 1948 dan secara resmi terbentuk TNI di Aceh pada 13 Juni 1948 dengan nama Divisi X. Keberhasilan ini, dapat dijadikan sebagai acuan bahwa Daud Beureueh benar-benar seorang republikan sehingga dapat mengangkat citranya di kalangan sipil maupun militer yang akan berimbas semakin besarnya pengaruh dirinya di Aceh. Kesediaan Laskar perjuangan dibubarkan kesatuannya dan bergabung dalam TNI, merupakan suatu prestasi yang gemilang dari kepemimpinan Daud Bereueh sebagai Gubernur Militer (Jakobi, 1992, hlm. 190). Namun akan begitu mengecewakan apabila Daud Beureueh gagal dalam melaksanakan tugasnya mengingat Aceh dalam kondisi politiknya lebih stabil dibandingkan dengan wilayah lain di Indonesia. Kegemilangannya ini tidak lepas pula dari posisi dirinya sebagai ketua PUSA. Pengalamannya dalam memimipin suatu organisasi berimbas pada kemampuan yang dimilikinya. Selain dengan adanya dukungan dari kalangan ulama yang merupakan kekuatan di sekelilingnya.

...akhirnya dengan pengaruh Tgk. Muhd. Daud Beureueh, sebagai Gubernur Militer, dan pengorbanan-pengorbanan barisan rakyat pejuang itu, semuanya bersedia dibubarkan dan senjatasenjatanya diserahkan kepada TNI. Sedangkan anggota divisi-divisi sebagian kecil saja yang masuk ke TNI. Sebagian besar, dengan sukarela kembali ke masyarakat dengan tidak meminta penampungan dan sumbangan atau fasilitas apa-apa (Ibrahimy, 2001, hlm. 52).

Bagi pemerintah pusat, keberhasilan pembentukan TNI di Aceh bagi Indonesia cukup membawa angin segar. Hal ini akan meningkatkan wibawa republik di daerah-daerah lain dan di mata Belanda serta dunia internasional, sebab kegagalan pembentukannya dapat dipandang sebagai ketidakberdayaan pemerintah pusat (Sjamsuddin, 1999, hlm. 246). Apabila yang terjadi adalah kegagalan, maka akan semakin mengindikasikan bahwa pemerintah pusat tidak berdaya dalam membentuk salah satu alat kelengkapan negara yang memegang peranan penting. Terlebih bahwa daerah Aceh merupakan satu-satunya wilayah di Indonesia yang tidak diduduki kembali oleh Belanda sehingga kemungkinan terbaik bisa terjadi. 
Tidak lama setelah Daud Beureueh membentuk TNI, Soekarno mengunjungi Aceh pada 16 Juni 1948. Soekarno menyatakan bahwa keadaan Indonesia yang semakin genting dan keperluan akan pesawat terbang untuk hubungan antar pulau dan kosolidasi kekuatan di pelosok Indonesia amat diperlukan. Maka dari itu, Soekarno dengan kata lain meminta kepada masyarakat Aceh untuk memberikan dukungannya untuk keberlangsungan Republik Indonesia. Melihat keadaan itu, Daud Beureueh pun melakukan inisiatif untuk mengumpulkan dana yang berasal dari kalangan masyarakat Aceh. Para pengusaha Aceh yang tergabung dalam Gabungan Saudagar Indonesia Daerah Aceh (GASIDA) turut memberikan bantuan demi memenuhi keperluan pembelian pesawat terbang. Betapa besar karisma yang dimiliki oleh Daud Beureueh sehingga masyarakat Aceh dapat diluluhkan hatinya dalam pengumpulan dana untuk pembelian pesawat terbang.

Keberhasilan Daud Beureueh sebagai inisiator dalam proses pengumpulan dana menjadi angin segar bagi Pemerintah Indonesia, khususnya Soekarno. Setelah dana terkumpul, Soekarno pun melakukan pidato di hadapan masyarakat Aceh yang juga disaksikan pula oleh Daud Beureueh. Kelak, pesawat terbang yang dibeli dari hasil penggalangan dana masyarakat Aceh ini menjadi cikal bakal berdirinya maskapai penerbangan Indonesian Airways atau yang kemudian dikenal dengan Garuda Indonesia. Jabatan gubernur militer yang dipegang oleh Daud Beureueh bukan sembarang isapan jempol belaka melainkan mampu dijalankan dengan baik oleh Daud Beureueh

Di dalam melaksanakan tugas sebagai gubernur militer, Daud Beureueh dihadapkan kepada permasalahan dengan munculnya gerakan Sayid Ali. Gerakan ini menjalankan aksinya dengan mengeluarkan berbagai macam tuduhan negatif yang ditujukan kepada petinggi pemerintahan yang dirumuskan dalam Programma van Actie.

1. Bahwa merekayang telah dapat berhasil menduduki kursi-kursi pemerintahan, telah mengadakan suatu perkumpulan "Banteng Hitam".

2. "Bahwa mereka ini, terhadap setiap orang yang tidak termasuk perkumpulan ini, mengadakan satu front sehingga pemerintahan seluruhnya tetap dalam genggaman mereka dan segala kesalahankesalahan mereka tetap terpendam".

3. "Bahwa mereka melakukan berbagaiberbagai kecurangan dan kejahatan antara lain

a. Korupsi secara besar-besaran.

b. Melakukan perniagaan ilegal secara besar-besaran.

c. Melakukan pembunuhan atas mereka yang tidak disukai dan dianggap berbahaya bagi mereka.

d. Tidak mengurus baitul mal dan zakat sebgaimana mestinya.

e. Tidak mengindahkan peraturanperaturan dan instruksi dari pemerintah pusat.

f. Mempergunakan hasil-hasil tambang minyak dan perkebunan untuk kepentingan diri sendiri” (Amin, 2014, hlm. 34).

Pejabat-pejabat yang dimaksud memiliki posisi penting dalam pemerintahan sehingga kelompok yang tergabung dalam gerakan Sayid Ali dapat dengan mudah memberikan semacam 
tuduhan bahwa mereka melakukan tindakan korupsi yang dapat merugikan banyak pihak. Namun, gerakan ini pada akhirnya mampu dihentikan oleh Daud Beureueh dengan cara mengeluarkan maklumat gubernur militer dan ditangkaplah Sayid Ali sebagai pemimpin gerakan ini.

Posisi Indonesia terus mengalami situasi genting terlebih ketika terbentuk Pemerintah Darurat Republik Indonesia (PDRI) hingga berlangsungnya Konferensi Meja Bundar (KMB). Hasil dari KMB yang salah satunyaadalah pengakuankedaulatan bagi Indonesia bukan berarti secara otomatis Indonesia terlepas dari berbagai permasalahan yang menerpa. Salah satu polemik yang muncul pasca pengakuan kedaulatan antara lain mengenai perubahan status yang disandang oleh Provinsi Aceh. Perubahan status wilayah Aceh, khususnya pada masa revolusi telah mengalami beberapa kali perubahan. Pasca proklamasi kemerdekaan Republik Indonesia, wilayah Aceh dibentuk sebagai suatu keresidenan dari Provinsi Sumatera dan keadaan ini berlangsung hingga April 1946. Terjadi perubahan pada 16 April 1946 di mana Sumatera hanya dijadikan satu buah provinsi saja dan dibentuk tiga subprovinsi yang meliputi Subprovinsi Sumatera Utara, Sumatera Tengah, dan Sumatera Selatan. Jabatan gubernur ditujukan kepada pemimpin provinsi sedangkan jabatan gubernur muda ditujukan kepada pemimpin subprovinsi. Secara otomatis, wilayah Aceh tetap masuk ke dalam subprovinsi Sumatera Utara.

Perubahan kembali terjadi setelah ditetapkannya Undang-undang No. 10 Tahun 1948 yang berisi mengenai perubahan atas pembagian wilayah di Sumatera. Wilayah Sumatera dibagi ke dalam tiga wilayah, yakni Sumatera Utara, Sumatera Tengah, dan Sumatera Selatan sehingga ketiga wilayah yang sebelumnya berstatus sebagai subprovinsi telah mengalamai perubahan menjadi provinsi tersendiri. Peraturan ini diberlakukan pada 15 April 1948 dan ketiga wilayah ini dipimpin oleh seorang gubernur. Pada masa ini di seluruh Sumatera termasuk Aceh, diberlakukan pemerintahan militer karena terjadi Agresi Militer Belanda kedua sehingga urusan keamanan diserahkan kepada gubernur militer mengingat terjadi keadaan yang cukup tegang.

Ketika Pemerintah Darurat Indonesia (PDRI) menjalankan pemerintahan, dikeluarkan penetapan oleh Sjafruddin Prawiranegara selaku pengemban tugas pengganti presiden sebagai Wakil Perdana Menteri Republik Indonesia. Penetapan itu berupa Peraturan Wakil Perdana Menteri pengganti Peraturan Pemerintah No.8/Des./WKPM/49 yang menyatakan bahwa Aceh menjadi provinsi yang berdiri sendiri. Atas desakan para pemimpin Aceh, Syarifuddin Prawiranegara menggunakan kekuasaan luar biasanya ini untuk mengeluarkan keputusan pemerintah yang menjadikan Aceh sebagai provinsi tersendiri (Morris, 1990, hlm. 111). Mengingat ketika itu PDRI menjalankan pemerintahannya di Kutaraja yang notabene merupakan pusat pemerintahan Pemerintah Daerah Aceh sehingga memungkinkan kedekatan para pemimpin Aceh dengan Sjafruddin Prawiranegara tidak dapat terelakkan. Di samping itu Sjafruddin Prawiranegara mengakui keunikan sejarah Aceh dan kepentingan serta kesetiaannya kepada Republik selama revolusi (Kahin, 2008, hlm, 259). 
Pada tanggal 1 Januari 1950 Aceh dijadikan sebagai provinsi dan Daud Beureueh diangkat menjadi Gubernur Aceh, sesudah ia diberhentikan sebagai Gubernur Militer (Ismuha, 1983, hlm. 92). Namun, keadaan ini tidak berlangsung lama. Sebab telah terjadi upaya konsolidasi antara Negara Republik Indonesia (NRI) dan Republik Indonesia Serikat (RIS) yang merupakan negara dengan bentuk federasi yang dibentuk berdasarkan Konferensi Meja Bundar, menghasilkan kesepakatan dengan membentuk Negara Kesatuan Republik Indonesia (NKRI). RIS pun dibubarkan pada 19 Mei 1950. Pembentukan sepuluh provinsi dalam NKRI ini ditetapkan berdasarkan Peraturan Pemerintah No. 21 Tahun 1950, yang meliputi Provinsi Sumatera Utara, Sumatera Tengah, Sumatera Selatan, Kalimantan, Sulawesi, Jawa Barat, Jawa Tengah, Jawa Timur, Maluku, dan Sunda Kecil. Bentuk negara yang dipilih adalah negara kesatuan meskipun tidak sedikit pihak yang tetap menginginkan bentuk negara serikat atau federasi. Sebab, pemerintah pusat menganggap bahwa bentuknegarakesatuan merupakan sebagai bentuk yang cocok dengan kepribadian bangsa Indonesia. Hal ini sejalan dengan situasi politik yang belum stabil pasca pengakuan kedaulatan sehingga Indonesia memerlukan pemersatu yang tergambar dalam bentuk negara yang dipilih.

Ketiadaan Provinsi Aceh dalam peraturan pemerintah tersebut membuat permasalahan baru perihal perubahan status yang dimiliki oleh Aceh. Mayoritas para pemimpin di Aceh tetap menginginkan Aceh dijadikan sebagai suatu provinsi tersendiri. Tidak terkecuali Daud Beureueh yang sebelumnya telah ditetapkan sebagai Gubernur Aceh pasca keputusan yang disahkan oleh Wakil Perdana Menteri, Sjafruddin Prawiranegara. Untuk menangani sikap keras kepala para pemimpin Aceh ini, pemerintah pusat mengirimkan suatu panitia penyelidik mengenai pembentukan Provinsi Aceh yang diketuai oleh Menteri Dalam Negeri (Surachman dan Kutoyo, 1977, hlm. 185). Terhitung beberapa orang pejabat tinggi pemerintah pusat seperti Sjafuddin Prawiranegara dan Menteri Negeri Mr. Assaat, Wakil Presiden Mohammad Hatta dan Perdana Menteri Mohammad Natsir mengunjungi Aceh untuk mendorong agar menerima penggabungan (Kahin, 2008, hlm. 260).

Penggabungan Aceh ke dalam Provinsi Sumatera Utara bisa dianggap pula sebagai suatu kemajuan karena memungkinkan penghilangan pandangan bahwa masyarakat Aceh adalah masyarakat yang bersifat kedaerahan yang hanya menerima satu golongan saja tanpa membaur dengan masyarakat daerah lain. Hal ini akan memberikan manfaat karena kesempatan bekerja sama dalam berbagai hal akan saling menguntungkan. Namun, para pemimpin Aceh termasuk Daud Beureueh menilai bahwa Provinsi Aceh merupakan representasi identitas keislaman mereka (Djumala, 2013, hlm. 29). Tradisi masyarakat Aceh yang mengakar kuat sejak dahulu terbentuk atas peran penting ajaran Islam sehingga dalam setiap sendi kehidupan masyarakat Aceh selalu memiliki keterkaitan dengan unsur keislaman. Di samping itu, pembentukan Provinsi Aceh ini didasarkan atas kemauan rakyat. Aceh minta mengurus sendiri dalam bentuk provinsi guna lekas tercapai kebahagiaan rakyat yang berarti pertolongan besar untuk pemerintah pusat (Kementerian Penerangan, 1953, hlm. 408). 
Berdasarkan Peraturan Pemerintah No. 21 Tahun 1950, pemerintah pusat yang diwakili oleh Perdana Menteri Mohammad Natsir, pada 23 Januari 1951 membubarkan Provinsi Aceh dan mengabungkannya dengan Provinsi Sumatera Utara (Djumala, 2013, hlm. 28). Tentu saja keputusan tersebut membuat Daud Beureueh bereaksi. Meski sebelumnya ia telah menaruh harapan kepada Mohammad Natsir agar mampu mempertimbangkan kembali keinginannya dan masyarakat Aceh, tetapi tetap saja pemerintah pusat mengetuk palu bahwa Aceh digabungkan dalam Provinsi Sumatera Utara.

Akibat dari perubahan status wilayah Aceh ini berdampak kepada munculnya benih-benih perlawanan yang dilakukan oleh Daud Beureueh. Ia menilai bahwa pemerintah pusat, dalam hal ini Soekarno tidak menepati janji. Hal ini seperti yang telah dibicarakan Daud Beureueh ketika Soekarno berkunjung ke Aceh pada pertengahan Juni 1948. Soekarno sempat memberikan tanggapannya kepada Daud Beureueh perihal keinginan untuk menjadikan Aceh sebagai wilayah yang menganut dan menerapkan syariat Islam. Kekecewaan Daud Beureueh terhadap pemerintah pusat mencapai puncak ketika ia memutuskan untuk bergabung ke dalam dalam gerakan Darul Islam/Tentara Islam Indonesia (DI/TII) yang sebelumnya telah diproklamasikan di Jawa Barat oleh S. M. Kartosoewirjo pada pada tanggal 7 Agustus 1949. Daud Beureueh benar-benar merasa kecewa atas keputusan yang dilakukan pemerintah pusat yang seakan-akan melupakan kontribusinya dan jasa-jasa dari masyarakat Aceh ketika membantu perjuangan bagi tegaknya Republik Indonesia.

\section{SIMPULAN}

Ketika masa revolusi berlangsung di Aceh, kondisi politik maupun kondisi sosial ekonomi di Aceh menunjukkan ketidakstabilan. Kondisi politik berjalan penuh dinamika karena adanya berbagai organisasi ketentaraan dan laskar perjuangan. Begitupun kondisi sosial ekonomi yang dapat dikatakan jauh dari memuaskan karena pewarisan keadaan dari Pemerintahan Jepang membuat lahan pertanian menjadi kurang produktif dan nilai dari mata uang yang mengalami inflasi. Ditambah adanya blokade dari Belanda. Para ulama Aceh, termasuk Daud Beureueh mengeluarkan maklumat bersama untuk melawan Belanda.

Ketika Peristiwa Cumbok, Daud Beureueh melakukan upaya dengan meyakinkan pemerintah daerah untuk memerhatikan konflik yang sedang berlangsung. Selain itu, ia pun memerintahkan pengerahan pasukan Mujahidin untuk memberikan perlawanan kepada kaum uleebalang di Pidie. Ia pun mampu menghentikan gerakan TPR pimpinan Husin Al Mujahid yang ambisius. Selama menjabat sebagai Gubernur Militer Daerah Aceh, Langkat, dan Tanah Karo, Daud Beureueh mampu membentuk TNI dengan cara meleburkan laskar perjuangan. Namun, diadakan proses seleksi sehingga tidak seluruh anggota dari laskar perjuangan bisa masuk ke dalam tubuh TNI. Selain itu, Daud Beureueh menjadi inisiator pengumpulan dana untuk pembelian pesawat terbang bagi Pemerintah Indonesia. Ia pun mampu menghentikan gerakan Sayid Ali yang mempropagandakan kebusukan pejabat di pemerintahan lokal Aceh. Sikap Daud Beureueh adalah menolak ketika Aceh 
digabungkan ke dalam Provinsi Sumatera Utara sehingga hal ini berujung kepada kekecewaannya kepada pemerintah pusat dan Soekarno.

\section{DAFTAR PUSTAKA}

Buku

Amin, S. M. (2014). Memahami sejarah konflik Aceh. Jakarta: Yayasan Obor

Dewanto, N. (Penyunting). (2011). Daud Beureueh pejuang kemerdekaan yang berontak. Jakarta: KPG dan Tempo

Djumala, D. (2013). Soft power untuk Aceh. Jakarta: Gramedia

Gottschalk, L. (1983). Mengerti sejarah. Jakarta: UI Press

Ibrahimy, M .N. E. (2001). Peranan Teungku Muhammad Daud Beureueh dalam Pergolakan di Aceh. Jakarta: Media Dakwah

Iskandar, M. (2000). Peranan elit agama pada masa revolusi kemerdekaan Indonesia. Jakarta: Depdiknas

Ismail, M. G. (1995). Ekonomi pada masa revolusi kemerdekaan di Aceh (19451949). Dalam Ghazali, Z (Penyunting). (1995). Sejarah lokal: Kumpulan makalah diskusi (151-167). Jakarta: Proyek IDSN Depdikbud

Ismuha. (1983). Ulama Aceh dalam perspektif sejarah. Dalam Abdullah, T. (Penyunting). (1983). Agama dan perubahan sosial (1-109). Jakarta: Rajawali Pers

Jakobi, T. A. K. (1992). Aceh daerah modal: Long march ke Medan Area. Jakarta: Yayasan Seulawah RI-001

Kahin, A. (2008). Dari pemberontakan ke integrasi. Jakarta: Yayasan Obor

Kementerian Penerangan. (1953). Republik Indonesia: Propinsi Sumatera Utara. Jakarta: Kementerian Penerangan
Kodam I/Iskandar Muda. (1972). Dua windu Kodam Iskandar Muda. Banda Aceh: Sejarah Militer Kodam I/ Iskandar Muda

Lapian, A. B. dkk. (1996). Terminologi sejarah 1945-1950 dan 1950-1965.

Jakarta: Proyek IDSN Depdikbud

Morris, E. (1990). Aceh: Revolusi sosial dan pandangan Islam. Dalam Kahin, A. (Penyunting). (1990). Pergolakan daerah di awal kemerdekaan (89-116). Jakarta: Graffiti Pers

Nasution. A. H. (1977). Sekitar perang kemerdekaan Indonesia jilid I. Bandung: Disjarah AD dan Angkasa

Saleh, H. (1992). Mengapa Aceh bergejolak. Jakarta: Graffiti Pers

Shiraishi, S. (1988). Pemerintah militer Jepang di Aceh 1942-1945. Dalam Nagazumi, A. (Penyunting). (1988). Pemberontakan Indonesia pada masa Pendudukan Jepang (38-82). Jakarta: Yayasan Obor Indonesia

Sjamsuddin, N. (1999). Revolusi di Serambi Mekah: Perjuangan kemerdekaan dan pertarungan politik di Aceh 1945-1949. Jakarta: UI Press

Sufi, M. R, dkk. (1997). Sejarah Kotamadya Banda Aceh. Banda Aceh: Balai Pelestarian Sejarah dan Nilai Tradisional Banda Aceh

Surachman dan Kutoyo, S. (Penyunting). (1977). Sejarah daerah Propinsi Daerah Istimewa Aceh. Jakarta: Proyek Penelitian Pencatatan Kebudayaan Daerah

Tippe, S. (2000). Aceh di persimpangan jalan. Jakarta: Pustaka Cidesindo

Wahidy, H. (1960). Mengenang kembali semangat dan tekad 17 Agustus '45 dalam Seksi Penerangan/ Dokumentasi Komite Musjawarah 
Angkatan 45 Daerah

Istimewa Atjeh. (1960). Modal revolusi 45 (72-80). Banda Aceh:

Zamzami, A. (1990). Jihad akbar di Medan Area. Jakarta: Bulan Bintang Artikel dalam Jurnal
Fahlevi, W. dkk. (2015). Tinjauan historis pengaruh inflasi Indonesia terhadap ketahanan nasional tahun 1945-1950. Pesagi (Jurnal Pendidikan dan Penelitian Sejarah), 4, (2), hlm 1-12 